\title{
The Relationship between Risk Factors and Microalbumiuria for Ischemic Stroke- A Case Control Study
}

\author{
MD. SHAHEEN WADUD ${ }^{1}$, AMINUR RAHMAN ${ }^{2}$, MOHAMMAD SELIM SHAHI ${ }^{3}$, AKTAKIB UDDIN \\ AHMED ${ }^{4}$ UTTAM KUMAR SAHA ${ }^{5}$, ZAHED ALI $^{4}$, NARAYAN CHANDRA KUNDU ${ }^{6}$, \\ SAKHAWAT HOSSAIN ${ }^{7}$, FIROZ AHMED QURAISHI ${ }^{8}$, MD. RAFIQUL ISLAM ${ }^{9}$
}

\begin{abstract}
:
Background: Epidemiologic studies have reported that microalbuminuria is a risk factor for stroke in men and a limited case control study found that the highest quintile of microalbuminuria values was associated with 13 fold increased risk for stroke. The goal of this study was designed to determine its relationship to risk factors for ischemic stroke. Materials and Methods: It was a prospective observational study conducted in the Department of Neurology, Sir Salimullah Medical College \& Mitford Hospital, Dhaka, Bangladesh. Fifty consecutive patients with ischemic stroke were enrolled in this study, with at least two risk factors that fulfilled the inclusion criteria and were confirmed by CT or MRI of brain. Equal number of controls of same age group without stroke who had at least two risk factors was compared with the case group. The patients were assessed clinically with structured questionnaire including blood pressure, height and weight, and monitoring blood glucose and microalbuminuria. Results: Microalbuminuria was found $58.0 \%$ in patients with ischemic stroke. Patients who had diabetes mellitus will have 13.86 times the risk for developing of microalbuminuria $(p<0.05)$. Patients who had hypertension will have 4.19 times the risk of developing microalbuminuria $(p<0.05)$ and BMI $\left(e " 23 \mathrm{~kg} / \mathrm{m}^{2}\right)$ will have 4.24 times the risk of developing microalbuminuria $(p<0.05)$. Whereas TIA, IHD, dyslipidemia, smoking and positive family history were not significantly $(P>0.05)$ associated with microalbuminuria in patients with ischemic stroke. Conclusion: The findings of this study show that diabetes is the factor most closely associated with microalbuminuria followed by HTN and BMI >23 kg/ $m^{2}$ with statistically significance in patients with ischemic stroke.
\end{abstract}

Keywords: Microalbuminuria, risk factors, Ischemic stroke

Abbreviation: TIA (transient ischemic stroke), HTN (hypertension), BMI (basal metabolic index), IHD(ischemic heart disease)

\section{Introduction:}

Stroke is a neurological disease, which is a major cause of death and disability worldwide. Stroke kills about five million people each year making this the second major cause of death worldwide. At least fifteen million others have non-fatal stroke annually and about a third are disabled as a consequence ${ }^{1}$. The word stroke is used to refer to a clinical syndrome, of presumed vascular origin, typified by rapidly developing signs of focal or global disturbance of cerebral functions lasting more than 24 hours or leading to death ${ }^{2}$. Among Risk factors for stroke advance age, male sex , hypertension, previous stroke or transient ischemic attack (TIA), diabetes mellitus, high cholesterol, smoking, and mitral valvular heart disease with atrial fibrillation

1. Resident, Department of Neurology, Sir Salimullah Medical College \& Mitford Hospital, Dhaka Bangladesh

2. Registrar, Department of Neurology, Sir Salimullah Medical College \& Mitford Hospital, Dhaka Bangladesh

3. Registrar, Department of Hematology, Sir Salimullah Medical College \& Mitford Hospital, Dhaka. Bangladesh

4. Associate Professor, Department of Neurology, Sir Salimullah Medical College \& Mitford Hospital, Dhaka Bangladesh.

5. Associate Professor Department of Clinical Neurology, National Institute of Neurosciences\& Hospital, Dhaka Bangladesh

6. Associate Professor Department of Neurology, Shaheed Suhrawardy Medical College, Dhaka Bangladesh

7. Professor, Department of Neurology , Sir Salimullah Medical College \& Mitford Hospital, Dhaka Bangladesh

8 Professor Department of Interventional Neurology, National Institute of Neurosciences\& Hospital, Dhaka Bangladesh

9. Professor, Department of Neurology, Bangabandhu sheikh Mujib Medical University, Dhaka, Bangladesh 
are well established in ischemic stroke ${ }^{3}$. Microalbuminuria is commonly thought of as an important risk factor for kidney disease, but recently studies have emerged highlighting microalbuminuria as an important, independent marker for endothelial dysfunction and ischemic stroke. Increasing the awareness of microalbuminuria as an early prognostic indicator of stroke risk ${ }^{4-8}$.

Microalbuminuria is the excretion of greater than $30 \mathrm{mg}$ and less than $300 \mathrm{mg}$ a day of albumin in the urine. The normal urinary albumin is less than $30 \mathrm{mg}$ per 24 hours $^{9}$. Nephrologists and diabetologist measure microalbuminuria to monitor the development and progression of kidney disease, but now studies have shown a clear relationship between microalbuminuria and cardiovascular events ${ }^{10}$.Microalbuminuria is present in a section of population known to be risk for stroke, including people with type 1, type 2 diabetes, hypertension, endothelial dysfunction, and other feature of insulin resistance. The prevalence of microalbuminuria 20$40 \%$ in diabetes, $40 \%$ of poorly controlled hypertensive individual have microablbuminuria and that its prevalence increases with duration and severity of hypertention ${ }^{4,5}$. Hypertensive patients also have microalbuminuria more frequently have left ventricular hypertrophy, carotid artery thickening and other end organ damage ${ }^{6}$.

Microalbuminuria can also predict a deleterious cardiovascular prognosis in other individual, such as patient with dyslipidemia or the cluster of risk factors like metabolic syndrome, abdominal obesity, elevated triglycerides, and elevated fasting blood glucose ${ }^{5}$.

Although studies have shown that small increase in urinary excretion of albumin predict adverse renal and vascular events in patient with diabetes, hypertension, or both. But the exact mechanism particularly in stroke is unknown. Many researchers have hypothesized that microalbuminuria is associated with generalized endothelial dysfunction ${ }^{4}$.

The current consensus among researcher is that albumin passes through the vascular wall, and this increased permeability is a marker of endothelial dysfunction. In diabetic and hypertensive patient with microalbuminuria have shown that increase albumin leakage in the glomerulus is linked to enhance capillary permeability for albumin in the systemic vasculature ${ }^{4}$.

Researcher hypothesized that such leakage leads to hemodynamic strain and instability, which starts the atherosclerotic process, and eventually lead to adverse vascular event like Ischemic stroke ${ }^{7}$.Although microalbuminuria is associated with clinical risk factor for stroke, there is surprisingly little information regarding it as an independent risk factor for stroke or a predictor of stroke outcome. A large prospective study has reported that microalbuminuria is a risk factor for stroke in men and a limited case control study found that the highest quintile of microalbuminuria values was associated with 13 fold increased risk for stroke ${ }^{9}$.

\section{Materials and Methods:}

This prospective observational case-control study of microalbuminuria as risk factor for acute ischemic stroke was conducted for 50 consecutive male and female patients who were admitted in the Department of Neurology and Medicine of Sir Salimullah Medical College \& Mitford Hospital, Dhaka, Bangladesh from July 2011 to June 2012 (1 year). Criteria for inclusion in this study were :(1). First ever acute ischemic stroke,(2). CT scan or MRI suggestive for ischemic stroke, (3). Who have at least 2 risk factors like male, family history, diabetes mellitus(DM), dyslipidemia, transient ischemic attack (TIA), cigarette smoking, hypertension, high Body Mass Index (BMI) and (4). age $>25$ years. The patients age and sex match with the cases who fulfilled the criteria for at least 2 risk factors as male, family history, DM, dyslipidemia, TIA, cigarette smoking, hypertension, high BMI without stroke will be considered as control.

Clinical information including age, sex, history or current evidence of hypertension (HTN) [systolic blood pressure (SBP) $>150 \mathrm{mmHg}$ and diastolic BP $>90 \mathrm{mmHg}$ ], diabetes mellitus (DM), cardiac disease, were recorded for all subjects. Plasma glucose (Fasting, 2 hours after breakfast, Random blood glucose, Glycosylated hemoglobin A1c 
(HbA1c), fasting lipid profile( Minimum 8 hours fasting), first morning void urine sample for microalbumin estimation. Plasma glucose and cholesterol levels were measured with an Express 550 clinical chemistry autoanalyzer (Ciba Corning Diagnostic Corp) in fasting conditions of 8 to 10 hours. $\mathrm{HbA} 1 \mathrm{c}$ percentage was measured by HPLC, and the normal range was $4.5 \%$ to 6.5\%.Microalbuminuria was tested by Micral test (Roche diagnostic manufacturer, Ltd). This test was also based on the color shift of a monoclonal antibody to human albumin after binding of urinary albumin to antibody. It was a semi-quantitative screening tool and the results of this test were read as $0 \mathrm{mg} / \mathrm{L}, 20 \mathrm{mg} / \mathrm{L}, 50 \mathrm{mg} / \mathrm{L}$ and $100 \mathrm{mg} / \mathrm{L}$. A reading of $20 \mathrm{mg} / \mathrm{L}$ or more was considered positive, according to manufacturer's recommendation. Data were collected by a predesigned proforma. Patient's information was obtained through using patient's information sheet which involves questionnaire, clinical findings, and biochemical findings, CT scan / MRI of brain and Duplex study of the neck vessels, Echocardiogram. All the cases and controls were informed about the nature of the study. Their informed written consent was taken in a consent form before collecting data. Proper permission was taken from the concerned departments and local ethical committee.

Statistical analyses related with this study were performed by use of SPSS 16.0 package program. The data was expressed by descriptive statistical methods like average, frequency distribution, percentage, mean \& standard deviation as applicable. Comparison between groups was done by standard statistical test e.g. Chi-square test or other tests as applicable. Relationship between risk factor and microalbuminuria in ischemic stroke were investigated by odds ratio.

\section{Results:}

Mean age was found $57.96 \pm 12.83$ years in group I and $54.71 \pm 11.7$ years in group II. Mean difference was statistically non significant $(P>0.05)$ between two groups.

Males were predominant of the both groups, which was 28 cases(56.0\%) in group I and 26 cases(52.0\%) in group II. The difference was not statistically significant $(P>0.05)$ between two groups.

The mean BMI was found $22.47 \pm 4.68 \mathrm{~kg} / \mathrm{m}^{2}$ in group I and $23.35 \pm 4.72 \mathrm{~kg} / \mathrm{m}^{2}$ in group II. The mean difference was not statistically significant $(P>0.05)$ between two groups. BMle"23 was found $15(30 \%)$ in group I and $24(48 \%)$ in group II

$\mathrm{H} / \mathrm{O}$ of TIA was found $4(8.0 \%)$ in group I and $2(4.0 \%)$ in group II. HTN was found in $31(62.0 \%)$ and $40(80.0 \%)$ group I and group II respectively. DM was $19(38.0 \%)$ in group I and $28(56.0 \%)$ in group II.. Dyslipidaemia was $15(30.0 \%)$ in group I and $26(52.0 \%)$ in group II. Family history was found in $26(52.0 \%)$ and $38(76.0 \%)$ in group I and group II respectively. Smoker was $20(40.0 \%)$ in group I and 13(26.0\%) in group II. Drug history (HTN, DM, dyslipidaemia) was found in 30(60.0\%) in group I and 21(42.0\%) in group II. BMI (e"23 $\mathrm{kg} / \mathrm{m}^{2}$ ) was found $15(30.0 \%)$ in group I and $24(48.0 \%)$ in group II. HTN, dyslipidemia and family history difference was statistically significant $(P<0.05)$ between two groups.

Table-I

Age distribution of the study patients $(n=100)$

\begin{tabular}{|c|c|c|c|c|c|}
\hline \multirow[t]{2}{*}{ Age (in years) } & \multicolumn{2}{|c|}{ Group I(n=50) } & \multicolumn{2}{|c|}{ Group II(n=50) } & \multirow[t]{2}{*}{$P$ value } \\
\hline & $\bar{n}$ & $\%$ & $\bar{n}$ & $\%$ & \\
\hline d"30 & 1 & 2.0 & 1 & 2.0 & \\
\hline $31-40$ & 2 & 4.0 & 6 & 12.0 & \\
\hline $41-50$ & 12 & 24.0 & 21 & 42.0 & \\
\hline $51-60$ & 15 & 30.0 & 14 & 28.0 & \\
\hline $61-70$ & 8 & 16.0 & 5 & 10.0 & \\
\hline $71-80$ & 11 & 22.0 & 2 & 4.0 & \\
\hline$>80$ & 1 & 2.0 & 1 & 2.0 & \\
\hline $\begin{array}{l}\text { Mean } \pm \text { SD } \\
\text { Range (min-max) }\end{array}$ & \multicolumn{2}{|c|}{$\begin{array}{c}57.96 \pm 12.83 \\
(25-85)\end{array}$} & \multicolumn{2}{|c|}{$\begin{array}{c}54.71 \pm 11.7 \\
(30-90)\end{array}$} & $0.187^{\mathrm{ns}}$ \\
\hline
\end{tabular}

Group I: Case \& Group II: Control. s=significant, $P$ value reached from unpaired t-test. 
Table-II

Sex distribution of the study patients $(n=100)$

\begin{tabular}{|c|c|c|c|c|c|}
\hline \multirow[t]{2}{*}{ Sex } & \multicolumn{2}{|c|}{ Group I $(n=50)$} & \multicolumn{2}{|c|}{ Group II $(n=50)$} & \multirow[t]{2}{*}{ P value } \\
\hline & $n$ & $\%$ & $n$ & $\%$ & \\
\hline Male & 28 & 56.0 & 26 & 52.0 & $0.688^{\mathrm{ns}}$ \\
\hline Female & 22 & 44.0 & 24 & 48.0 & \\
\hline
\end{tabular}

ns=not significant, $P$ value reached from chi square test.

Table-III

Distribution of the study patients according to body mass index (BMI) (n=100)

\begin{tabular}{lccccc}
\hline BMI $\left(\mathrm{kg} / \mathrm{m}^{2}\right)$ & \multicolumn{2}{c}{ Group I $(\mathrm{n}=50)$} & \multicolumn{2}{c}{ Group II $(\mathrm{n}=50)$} & P value \\
& $\mathrm{n}$ & $\%$ & $\mathrm{n}$ & $\%$ & \\
\hline$<18.5$ & 9 & 18.0 & 3 & 6.0 & \\
$18.5-23$ & 26 & 52.0 & 23 & 46.0 & \\
$23-27.5$ & 12 & 24.0 & 17 & 34.0 & \\
e"27.5 & 3 & 6.0 & 7 & 14.0 & \multirow{2}{*}{$0.351^{\mathrm{ns}}$} \\
Mean \pm SD & \multicolumn{2}{c}{$22.47 \pm 4.68$} & \multicolumn{2}{c}{$23.35 \pm 4.72$} & \\
Range (min-max) & \multicolumn{2}{c}{$(15-36.16)$} & \multicolumn{2}{c}{$(14.86-36.5)$} & \\
\hline
\end{tabular}

ns=not significant,$P$ value reached from unpaired t-test.

Table-IV

Distribution of the study patients according to risk factors $(n=100)$

\begin{tabular}{|c|c|c|c|c|c|}
\hline \multirow[t]{2}{*}{ Risk factors } & \multicolumn{2}{|c|}{ Group I $(n=50)$} & \multicolumn{2}{|c|}{ Group II $(n=50)$} & \multirow[t]{2}{*}{$P$ value } \\
\hline & $\mathrm{n}$ & $\%$ & $\mathrm{n}$ & $\overline{\%}$ & \\
\hline \multicolumn{6}{|l|}{$\mathrm{H} / \mathrm{O} \mathrm{TIA}$} \\
\hline Yes & 4 & 8.0 & 2 & 4.0 & \multirow[t]{2}{*}{$0.338^{\text {ns }}$} \\
\hline No & 46 & 92.0 & 48 & 96.0 & \\
\hline \multicolumn{6}{|l|}{$\mathrm{HTN}$} \\
\hline Yes & 31 & 62.0 & 40 & 80.0 & \multirow{2}{*}{$0.047^{\mathrm{s}}$} \\
\hline No & 19 & 38.0 & 10 & 20.0 & \\
\hline \multicolumn{6}{|l|}{$\mathrm{DM}$} \\
\hline Yes & 19 & 38.0 & 28 & 56.0 & \multirow[t]{2}{*}{$0.071^{\text {ns }}$} \\
\hline No & 31 & 62.0 & 22 & 44.0 & \\
\hline \multicolumn{6}{|l|}{ Dyslipidemia } \\
\hline Yes & 15 & 30.0 & 26 & 52.0 & \multirow[t]{2}{*}{$0.025^{\mathrm{s}}$} \\
\hline No & 35 & 70.0 & 24 & 48.0 & \\
\hline \multicolumn{6}{|c|}{ Family history } \\
\hline Yes & 26 & 52.0 & 38 & 76.0 & \multirow[t]{2}{*}{$0.012^{\mathrm{s}}$} \\
\hline No & 24 & 48.0 & 12 & 24.0 & \\
\hline \multicolumn{6}{|l|}{ Smoking } \\
\hline Yes & 20 & 40.0 & 13 & 26.0 & \multirow[t]{2}{*}{$0.136^{\mathrm{ns}}$} \\
\hline No & 30 & 60.0 & 37 & 74.0 & \\
\hline \multicolumn{6}{|c|}{ Drug history (HTN, DM, Dyslipidaemia) } \\
\hline Yes & 30 & 60.0 & 21 & 42.0 & \multirow[t]{2}{*}{$0.071^{\text {ns }}$} \\
\hline No & 20 & 40.0 & 29 & 58.0 & \\
\hline \multicolumn{6}{|c|}{ BMI (e"23 kg/m²) } \\
\hline Yes & 15 & 30.0 & 24 & 48.0 & \multirow[t]{2}{*}{$0.065^{\text {ns }}$} \\
\hline No & 35 & 70.0 & 26 & 52.0 & \\
\hline
\end{tabular}

$\mathrm{s}=$ significant; $\mathrm{ns}=$ not significant, $\mathrm{P}$ value reached from chi square test. 
Mean systolic BP was found $142.5 \pm 27.26 \mathrm{mmHg}$ in group I and $136.22 \pm 33.7 \mathrm{mmHg}$ in group II. Mean diastolic BP was found $85.8 \pm 14.01 \mathrm{mmHg}$ and $81.71 \pm 16.72 \mathrm{mmHg}$ in group I and group II respectively. The difference was not statistically significant $(P>0.05)$ between two groups.

The mean fasting blood sugar was found $9.71 \pm 4.32$ in group I and $6.59 \pm 1.06$ in group II. The mean random blood sugar was found $9.0 \pm 4.36$ and $9.84 \pm 5.2$ in group I and group II respectively. Mean fasting blood sugar difference was statistically significant $(P<0.05)$ between two groups but not in random sugar groups.

Mean $\mathrm{HbA}_{1} \mathrm{C}$ was found $9.04 \pm 4.26 \%$ in group I and $7.02 \pm 2.05 \%$ in group II. The difference was statistically significant $(P<0.05)$ between two groups.

Positive microalbuminuria was found $29(58.0 \%)$ in group I and $16(32.0 \%)$ in group II. Negative microalbuminuria was $21(42.0 \%)$ in group I and $34(68.0 \%)$ group II. The difference was statistically significant $(P<0.05)$ between two groups.

Patients with microalbuminuria (in case group), $3(10.3 \%)$ had TIA, 22(75.9\%) had HTN, 17(58.6\%) had DM, 4(13.8\%) had IHD, 7(24.1\%) had dyslipidemia, 10(34.5\%) had smoking, 18(62.1\%) had family history and 12(41.4\%) had BMI (e"23 $\mathrm{kg} / \mathrm{m}^{2}$ )

Patients without microalbuminuria (in case group), 1(4.8\%) had TIA, 9(42.9\%) HTN, 2(9.5\%) DM, $1(4.8 \%)$ IHD, $8(38.1 \%)$ dyslipidemia, 10(47.6\%) smoking, $8(38.1 \%)$ family history and $3(14.3 \%)$ BMI $\left(<23 \mathrm{~kg} / \mathrm{m}^{2}\right)$.

The patients who had DM will have risk of microalbuminuria is 13.86 times of the patients who did not, but it has statistically significant $(95 \% \mathrm{Cl}$ $2.29 \%-92.64 \%$ ); p value $<0.05$ )

The patients who had HTN wil have risk of microalbuminuria is 4.19 times of the patients who did not, but it has statistically significant $(95 \% \mathrm{Cl}$ $1.07 \%-17.11 \%$ ); $p$ value $<0.05$ ).

The patients who had $\mathrm{BMI}\left(>23 \mathrm{~kg} / \mathrm{m}^{2}\right)$ will have risk of microalbuminuria is 4.24 times more of the patients who did not, but it has statistically significant (95\% Cl 0.87\%-23.06\%); p value<0.05).

The patients who had TIA will have risk of microalbuminuria is 2.31 times more of the patients who did not have TIA. It is not statistically significant (95\% Cl 0.19\%-62.29\%); $p$ value>0.05).

The patients who had dyslipidemia will have risk of microalbuminuria is 0.52 times more of the patients who did not, but it has no statistic significance (95\% $\mathrm{Cl} 0.13 \%-2.07 \%$ ); $\mathrm{p}$ value $>0.05$ ).

The patients who had smoking will have risk of microalbuminuria is 0.58 times more of the patients who did not, but it has no statistic significance $(95 \%$ $\mathrm{Cl} 0.16 \%-2.12 \%$ ); $\mathrm{p}$ value $>0.05$ )

The patients who had family history will have risk of microalbuminuria is 2.66 times more of the patients who did not, but it has no statistical significance $(95 \% \mathrm{Cl} 0.72 \%-10.04 \%) ; p$ value $>0.05$ )

Patient having positive microalbuminuria 3.84(95\% $\mathrm{Cl} 1.4 \%$ to $10.55 \%$ ) times more likely to have stroke. On the other hand patient having DM $2.17(95 \% \mathrm{Cl}$ $1.22 \%$ to $8.03 \%$ ) times more likely to have stroke and patient having HTN $1.92(95 \% \mathrm{Cl} 1.30 \%$ to $7.83 \%$ ) times more likely to have stroke. Other risk factors were not significantly $(P>0.05)$ associated with stroke in multivariate analysis.

Table V

Distribution of the study patients according to blood pressure $(n=100)$

\begin{tabular}{lccc}
\hline Blood Pressure $(\mathrm{mmHg})$ & Group I $(\mathrm{n}=50)$ & Group II $(\mathrm{n}=50)$ & P value \\
& Mean \pm SD & Mean \pm SD & \\
\hline Systolic & $142.5 \pm 27.26$ & $136.22 \pm 33.7$ & $0.308^{\text {ns }}$ \\
Range (min-max) & $(90-210)$ & $(90-240)$ & \\
Diastolic & $85.8 \pm 14.01$ & $81.71 \pm 16.72$ & $0.188^{\text {ns }}$ \\
Range (min-max) & $(50-120)$ & $(50-140)$ & \\
\hline
\end{tabular}

ns=not significant,$P$ value reached from unpaired $t$-test. 
Table-VI

Distribution of the study patients according to fasting blood sugar and random blood sugar $(n=100)$

\begin{tabular}{lccc}
\hline & Group I $(\mathrm{n}=50)$ & Group II $(\mathrm{n}=50)$ & P value \\
& Mean \pm SD & Mean \pm SD & \\
\hline Fasting blood sugar & $9.71 \pm 4.32$ & $6.59 \pm 1.06$ & $0.001^{\mathrm{s}}$ \\
Range (min-max) & $(5.4-17)$ & $(5-8.1)$ & \\
Random blood sugar & $9.0 \pm 4.36$ & $9.84 \pm 5.2$ & $0.383^{\text {ns }}$ \\
Range (min-max) & $(5.2-21)$ & $(5-25)$ & \\
\hline
\end{tabular}

$s=$ significant; ns=not significant. $P$ value reached from unpaired t-test.

Table VII

Distribution of the study patients according to $\mathrm{HbA}_{1} \mathrm{C}(n=100)$

\begin{tabular}{lccc}
\hline & Group I $(\mathrm{n}=50)$ & Group II $(\mathrm{n}=50)$ & P value \\
& Mean $\pm \mathrm{SD}$ & Mean \pm SD & \\
\hline $\mathrm{HbA}_{1} \mathrm{C}$ & $9.04 \pm 4.26$ & $7.02 \pm 2.05$ & $0.003^{\mathrm{s}}$ \\
Range (min-max) & $(5.4-16.87)$ & $(5.07-11.7)$ & \\
\hline
\end{tabular}

$s=$ significant, $P$ value reached from unpaired t-test.

Table-VIII

Distribution of the study patients according to microalbuminuria $(n=100)$

\begin{tabular}{|c|c|c|c|c|c|}
\hline \multirow[t]{2}{*}{ Microalbuminuria } & \multicolumn{2}{|c|}{ Group I(n=50) } & \multicolumn{2}{|c|}{ Group II $(n=50)$} & \multirow[t]{2}{*}{ P value } \\
\hline & $\mathrm{n}$ & $\%$ & $n$ & $\%$ & \\
\hline Positive (30-299 mg/24h) & 29 & 58.0 & 16 & 32.0 & $0.008^{\mathrm{s}}$ \\
\hline Negative (<30 mg/24h) & 21 & 42.0 & 34 & 68.0 & \\
\hline
\end{tabular}

$s=$ significant.$P$ value reached from chi square test.

Table-IX

Relationship of risk factors with microalbuminuria for ischemic stroke patients $(n=50)$.

\begin{tabular}{|c|c|c|c|c|c|c|}
\hline \multirow[t]{3}{*}{ Risk factors } & \multicolumn{4}{|c|}{ Microalbuminuria } & \multirow[t]{3}{*}{ OR $(95 \% \mathrm{Cl})$} & \multirow[t]{3}{*}{$P$ value } \\
\hline & \multicolumn{2}{|c|}{ Yes $(n=29)$} & \multicolumn{2}{|c|}{$\mathrm{No}(\mathrm{n}=21)$} & & \\
\hline & $\mathrm{n}$ & $\%$ & $\mathrm{n}$ & $\%$ & & \\
\hline $\mathrm{DM}$ & 17 & 58.6 & 2 & 9.5 & $13.86(2.29-92.64)$ & $0.001^{\mathrm{s}}$ \\
\hline HTN & 22 & 75.9 & 9 & 42.9 & $4.19(1.07-17.11)$ & $0.018^{s}$ \\
\hline BMI (e"23 kg/m²) & 12 & 41.4 & 3 & 14.3 & $4.24(0.87-23.06)$ & $0.039^{s}$ \\
\hline TIA & 3 & 10.3 & 1 & 4.8 & $2.31(0.19-62.29)$ & $0.436^{\text {ns }}$ \\
\hline Dyslipidemia & 7 & 24.1 & 8 & 38.1 & $0.52(0.13-2.07)$ & $0.287^{\mathrm{ns}}$ \\
\hline Smoking & 10 & 34.5 & 10 & 47.6 & $0.58(0.16-2.12)$ & $0.349^{\text {ns }}$ \\
\hline Family history & 18 & 62.1 & 8 & 38.1 & $2.66(0.72-10.04)$ & $0.093^{\text {ns }}$ \\
\hline
\end{tabular}

ns=not significant,$P$ value reached from chi square test. 
Table-X

Multiple Logistic regression models for risk factors associated with ischemic stroke.

\begin{tabular}{lcccc}
\hline & OR & \multicolumn{2}{c}{$95.0 \% \mathrm{Cl}$ for OR } & P value \\
\cline { 2 - 4 } & & Lower & Upper & \\
\hline Microalbuminuria & 3.84 & 1.40 & 10.55 & $0.009 \mathrm{~s}$ \\
DM & 2.17 & 1.22 & 8.03 & $0.012 \mathrm{~s}$ \\
HTN & 1.92 & 1.30 & 7.83 & $0.039 \mathrm{~s}$ \\
H/O TIA & 0.58 & 0.28 & 1.55 & $0.461 \mathrm{~ns}$ \\
Dyslipidemia & 0.36 & 0.14 & 0.95 & $0.889 \mathrm{~ns}$ \\
Family History & 0.26 & 0.09 & 0.75 & $0.279 \mathrm{~ns}$ \\
Smoking & 1.27 & 0.44 & 3.66 & $0.656 \mathrm{~ns}$ \\
BMI(e"23 kg/m $\mathrm{m}^{2}$ ) & 0.91 & 0.34 & 2.44 & $0.848 \mathrm{~ns}$ \\
Constant & 3.51 & 0.28 & 17.03 & $0.101 \mathrm{~ns}$ \\
\hline
\end{tabular}

$\mathrm{S}=$ significant; ns=not significant

\section{Discussion:}

This case control study was carried out with an aim to determine the incidence of microalbuminuria in patients with ischemic stroke and to determine the relationship between the risk factors for ischemic stroke and microalbuminuria .

A total number of 50 consecutive patients having first ever ischemic stroke and 50 patients without ischemic stroke but both had at least two risk factors according to inclusion criteria, were considered as group I and group II respectively. The present study findings were discussed and compared with previously published relevant studies.

In this current study in Table I, it was observed that the mean age was $57.96 \pm 12.83$ years with range from 25 to 85 years in group I and $54.71 \pm 11.7$ years with range from 30 to 90 years in group II. The mean difference of age was not statistically significant $(P>0.05)$ between two groups. In a recent study showed the mean age was $66.1 \pm 12.7$ years with range from 28-90 years in patients having ischemic stroke ${ }^{9}$. In another study, found mean age were $59.1 \pm 8.3$ years and $59.3 \pm 10.4$ years in patients having ischemic stroke and without ischemic stroke respectively which is similar with this study ${ }^{11}$.

Regarding the sex incidence (Table II), it was observed that male predominant in both groups, which was $56.0 \%$ in group I and $52.0 \%$ in group II. Male to female ratio was $1.2: 1$ in the whole study patients. However, the male female difference was not statistically significant $(P>0.05)$ between two groups. Similarly, male predominant also observed in other studies 12,13 . In another study, it was observed that the male to female ratio was almost $1: 2$ in their study ${ }^{11}$.

In this study (Table III ), it was observed that the mean BMI was found $22.47 \pm 4.68 \mathrm{~kg} / \mathrm{m}^{2}$ in group I and $23.35 \pm 4.72 \mathrm{~kg} / \mathrm{m}^{2}$ in group II, which was almost similar between two groups. No statistical significant $(P>0.05)$ difference was found between two groups. A a recent study, they showed higher mean $\mathrm{BMI}^{12}$, where the authors found the mean BMI was $27.0 \pm 4.3 \mathrm{~kg} / \mathrm{m}^{2}$ and $24.8 \pm 3.0 \mathrm{~kg} / \mathrm{m}^{2}$ in group I and group II respectively. A another study, the mean BMI was $27.9 \pm 4.1 \mathrm{~kg} / \mathrm{m}^{2}$ in group I and $28.3 \pm 4.8 \mathrm{~kg} / \mathrm{m}^{2}$ in group $\mathrm{II}^{14}$. In another study it was was observed that the mean BMI was $29.5 \pm 3.6$ $\mathrm{kg} / \mathrm{m}^{2}$ and $27.2 \pm 1.8 \mathrm{~kg} / \mathrm{m}^{2}$ in group I and group II respectively ${ }^{16}$. They have stated that the higher $\mathrm{BMI}$ range maybe due to their body surface area in their study patients.

Regarding the risk factors associated with ischemic stroke (Table IV), it was observed that the previous history of TIA was found $8.0 \%$ in group I and $4.0 \%$ in group II. HTN was found in $62.0 \%$ and $80.0 \%$ group I and group II respectively. DM was found in $38.0 \%$ in group I and $56.0 \%$ in group II. Family history was found in $52.0 \%$ and $76.0 \%$ in group I and group II respectively. Smoker was 
$40.0 \%$ in group I and $26.0 \%$ in group II. Drug history (HTN, DM, dyslipidemia) was found in $60.0 \%$ in group I and $42.0 \%$ in group II. BMI (e"23 kg/m2) was found $30.0 \%$ in group I and $48.0 \%$ in group II. HTN, dyslipidemia and family history were significantly $(\mathrm{P}<0.05)$ higher in group II. In a similar study, hypertension was found in $10.2 \%$ and $13.8 \%$ in group I and group II respectively, which is less than the current study ${ }^{11}$. This may be due to the current study patients mostly came from low socio-economic status and they didn't received any antihypertensive drugs, as they had lack of health education and awareness. The authors also observed diabetes $42.4 \%$ in group I and $55.5 \%$ in group II. Smoker was found $23.7 \%$ in group I and $16.1 \%$ in group II, which are almost similar with the current study ${ }^{9}$. In another study, showed that $64.0 \%$ and $45.0 \%$ were smoker in group I and group II respectively, which was higher than the current study ${ }^{12}$.

In this series in Table $\mathrm{V}$, it was observed that the mean systolic BP was found $142.5 \pm 27.26 \mathrm{mmHg}$ with range from 90 to $210 \mathrm{mmHg}$ in group I and $136.22 \pm 33.7 \mathrm{mmHg}$ with range from 90 to 240 $\mathrm{mmHg}$ in group II. Mean diastolic BP was found $85.8 \pm 14.01 \mathrm{mmHg}$ with range from 50 to $120 \mathrm{mmHg}$ and $81.71 \pm 16.72 \mathrm{mmHg}$ with range from 50 to 140 $\mathrm{mmHg}$ in group I and group II respectively. The mean systolic and diastolic BP were higher in group I but not statistically significant $(P>0.05)$ between two groups. Similarly, the higher mean systolic and diastolic BP were also observe ${ }^{12}$, where the mean systolic BP was found $173.0 \pm 16.0 \mathrm{mmHg}$ and $162.0 \pm 8.0 \mathrm{mmHg}$ in group I and group II respectively. Similarly, the mean diastolic BP was found $98.0 \pm 8.0 \mathrm{mmHg}$ in group I and $101.0 \pm 8 \mathrm{mmHg}$ in group II, which are compatible with the current study. On the other hand, a recent study showed the mean systolic BP was $137 \pm 13 \mathrm{mmHg}$ and $128 \pm 11 \mathrm{mmHg}$ in group I and group II respectively ${ }^{15}$.The mean diastolic BP was 78.6 \pm 9.9 $\mathrm{mmHg}$ in group I and $75.6 \pm 7 \mathrm{mmHg}$ in group II, which are compatible with the current study.

In this current study in Table VI was observed that the mean fasting blood sugar was found $9.71 \pm 4.32$ $\mathrm{mmol} / \mathrm{l}$ varied from 5.4 to $17 \mathrm{mmol} / \mathrm{l}$ in group I and $6.59 \pm 1.06 \mathrm{mmol} / \mathrm{l}$ varied from 5.0 to $8.1 \mathrm{mg} / \mathrm{dl}$ in group II. Random blood sugar was found $9.0 \pm 4.36$ $\mathrm{mmol} / \mathrm{l}$ varied from 5.2 to $21 \mathrm{mmol} / \mathrm{l}$ and $9.84 \pm 5.2$ $\mathrm{mmol} / \mathrm{l}$ varied from 5.0 to $25 \mathrm{mmol} / \mathrm{l}$ in group I and group II respectively. Mean fasting blood sugar was significantly $(\mathrm{P}<0.05)$ higher in group I, whereas blood sugar was almost similar between two groups. In another study showed the mean fasting blood sugar was $7.7 \pm 2.7 \mathrm{mmol} / \mathrm{l}$ in group I and $8.2 \pm 2.6$ $\mathrm{mmol} / \mathrm{l}$ in group $\mathrm{II}^{16}$.

In this present series (Table VII), it was observed that the mean $\mathrm{HbA}_{1} \mathrm{C}$ was found $9.04 \pm 4.26 \%$ with range from 5.4 to $16.87 \%$ in group I and $7.02 \pm 2.05 \%$ with range from 5.07 to $11.7 \%$ in group II. The mean $\mathrm{HbA}_{1} \mathrm{C}$ was significantly $(\mathrm{P}<0.05)$ higher in group I patients. Almost similar findings were observed in a study, where they found the mean $\mathrm{HbA}_{1} \mathrm{C}$ was $8.8 \pm 1.3 \%$ and $7.1 \pm 1.5 \%$ in group I and group II respectively ${ }^{16}$. In similar studies, it was found that the mean $\mathrm{HbA}_{1} \mathrm{C}$ was $7.3 \pm 1.3 \%$ in group I and $6.5 \pm 1.3 \%$ in group $\|^{14,1}$ All these results support the present study.

Recently in a study it was revealed that, in the general population, microalbuminuria had a prognostic significance in patients with stroke, independently predicting recurrent strokes and mortality ${ }^{18}$. In another study, it was observed that microalbuminuria was independently associated with carotid artery intima-media thickness in nondiabetic individuals in the Insulin Resistance and Atherosclerosis Study, USA ${ }^{19}$. Carotid intimamedia thickness is a risk factor for stroke and coronary heart disease 20 .

In this current study (Table VIII), it was observed that positive microalbuminuria was found $58.0 \%$ in group I and $32.0 \%$ in group II. Negative microalbuminuria was $42.0 \%$ and $68.0 \%$ in group I and group II respectively. Positive microalbuminuria was significantly $(P<0.05)$ higher in patient with ischemic stroke. In another study showed that positive microalbuminuria was $64.0 \%$ and $25.0 \%$ in group I and group II respectively ${ }^{12}$. Beamer et al. showed microalbuminuria $29.9 \%$ in group I and $19.6 \%$ in group II patients ${ }^{13}$. The above findings are consistent with the current study.

A total of 50 patients having ischemic stroke, out of which $29(58.0 \%)$ and $21(42.0 \%)$ patients with 
microalbuminuria and without microalbuminuria respectively. In this present study (Table IX), it was observed that in patients having microalbuminuria with ischemic stroke patients that $58.6 \%$ had DM, 75.9\%had HTN, 41.4\% BMI e"23 $\mathrm{kg} / \mathrm{m}^{2}, 10.3 \%$ had TIA, $24.1 \%$ dyslipidemia, $34.5 \%$ smoker and $62.1 \%$ had positive family history. On the other hand, patients without microalbuminuria in patient with ischemic stroke, $9.5 \%$ had DM, $42.9 \%$ HTN $14.3 \%$ had $\mathrm{BMI}>23 \mathrm{~kg} / \mathrm{m} 2,4.8 \%$ had TIA, $38.1 \%$ dyslipidaemia, $47.6 \%$ smoker and $38.1 \%$ had positive family history.

Recent study showed out of 139 hypertensive patients, $23.74 \%$ had microalbuminuria and out of 55 diabetic patients, $54.55 \%$ had microalbuminuria and out of 98 patients with dyslipidemia, $24.49 \%$ had microalbuminuria, which is consistent with the current study ${ }^{9}$

In this present series it was observed that the patients who had diabetes mellitus will have 13.86 times more risk for developing microalbuminuria with $95 \% \mathrm{Cl} 2.29 \%-92.64 \%$; $(p<0.05)$. Patients who had HTN will have 4.19 times more the risk for developing microalbuminuria with $95 \% \mathrm{Cl} 1.07 \%$ $17.11 \%$; $(p<0.05)$. Patients who had BMI $>23 \mathrm{~kg} /$ $\mathrm{m}^{2}$ will have 4.24 times more risk for developing microalbuminuria with $95 \% \mathrm{Cl} 0.87 \%-23.06 \%$; $(p<0.05)$. Whereas TIA, dyslipidemia, smoking and positive family history were not significantly $(P>0.05)$ associated with microalbuminuria in patients with ischemic stroke. To determine which factors were independently associated with the risk of stroke, multivariate logistic regression analysis were performed and revealed microalbuminuria, DM, HTN remained as independent predictor for ischemic stroke. This finding showed that patients having positive microalbuminuria had $3.84(95 \%$ $\mathrm{Cl} 1.4 \%$ to $10.55 \%$ ) times more likely to have stroke ( Table X). On the other hand patient having DM $2.17(95 \% \mathrm{Cl} 1.22 \%$ to $8.03 \%)$ times more likely to have stroke and patient having HTN $1.92(95 \% \mathrm{Cl}$ $1.30 \%$ to $7.83 \%$ ) times more likely to have stroke. Other risk factors were not significantly $(P>0.05)$ associated with stroke in multivariate analysis.

A number of prospective studies observed that microalbuminuria predicts a cause of cardiovascular mortality in the general population ${ }^{21-23}$. The EPIC-
Norfolk study was the first report evaluating the prospective relationship between microalbuminuria and incidence of fatal and nonfatal cerebrovascular disease in the general population ${ }^{24}$. The mechanism of the association between albuminuria and stroke is still largely unknown and a focus of research and debate mentioned ${ }^{9}$. Several explanations have been suggested: Microalbuminuria may reflect universal endothelial dysfunction that might enhance the penetration of atherogenic lipoproteins into the arterial wall ${ }^{25}$. Microalbuminuria is a marker of established CVD ${ }^{26}$. Microalbuminuria and cerebrovascular disease are not causally related but rather reflect common determinants ${ }^{27,28}$. So this hospital based observational study, established the relationship between risk factor and microalbuminuria for ischemic stroke.

\section{Conclusion:}

This case control observational study showed that diabetes is the factor most closely associated with microalbuminuria followed by HTN and BMI e"23 $\mathrm{kg} / \mathrm{m}^{2}$ with statistically significance in patients with ischemic stroke.

\section{References:}

1. Safeer M, Tariq M, Rahman Ubaid ur. Frequency of risk cases in Naseer Teaching Hospital, Peshawar, Pakistan. Pak factors of cerebral infarction in stroke patients. A study of 100 cases. Pak J Med Sci, 2008; 24(1): 109-13.

2. World Health Organization Cerebrovascular disorders: a clinical and research classification.43. Geneva, World Health Organization; 1978.

3. Sacco RL, Benjamin EJ, Broderick JP, Dyken M, Easton JD, Feinberg WM, et al.. American Heart Association Prevention Conference. IV. Prevention and Rehabilitation of Stroke. Risk factors. Stroke . 1997 ; 28: 1507-17.

4. Montalescot G, Collet JP. Preserving cardiac function in the hypertensive patient: Why renal Parameters hold the key. Eur Heart J . 2005; 26: 2616-22.

5. Donnelly R, Yeung JM, Manning G,. Microalbuminuria: A common, independent 
cardiovascular risk factor, especially but not exclusively in type 2 diabetes.J Hypertens Suppl. 2003; 21(1):S7-12.

6. Naidoo DP. The link between Microalbuminuria, endothelial dysfunction and cardiovascular disease in diabetes. Cardiovasc J South Afr . 2002; 13:194-9

7. Valmadrid CT, Klein R, Moss SE, Klein, BEK. The risk of cardiovascular disease mortality associated with Microalbuminuria and gross proteinuria in persons with older-onset diabetes mellitus. ArchIntern Med. 2000; 160:1093-100.

8. Yusuf S, Sleight P, Pogue J, Bosch J, Davies $R$, Dagenais G J. Effects of an angiotensinconverting-enzyme inhibitor, ramipril, on cardiovascular events in high-risk patients: The Heart Outcomes Prevention Evaluation Study Investigators. N Eng J Med . 2000 ; 342:145-53.

9. Nidhinandana S, Chaisinanunkul N. The association between risk factors for ischemic stroke and microalbuminuria. J Med Assoc Thai . 2010; 93 Suppl 6:S55-9.

10. Woo J, Lau E, Kay R, Lam C.W, Cheung C.K, Swaminathan R, et al. A case control study of some Hematological and biochemical variables in acute stroke and their prognostic value. Neuroepidemiology.1990; 9: 315-20.

11. Guerrero-Romero F, Rodríguez-Moran M. Proteinuria Is an Independent Risk Factor for Ischemic Stroke in Non-Insulin-Dependent Diabetes Mellitus. Stroke. 1999; 30(9): 178791.

12. Galal M and Zoheir N. Microalbuminuria and endothelaial dysfunction in hypertensive patients with and without cerebral lacunar infarctions. Sci. Med.J. ESCME. 2003; 15: 3.

13. Beamer NB, Coull BM, Clark WM, Wynn M. Microalbuminuria in ischemic stroke.Arch Neurol, $1999 ; 56(6): 699-702$.

14. Alamdari IM, Aminisani N, Bashardoost B, Shamshirgaran SM, Khodamo-radzadeh M, Shokrabadi M, et al. Prevalence and Risk
Factors of Microalbuminuria in Type 2 Diabetic Patients in a Diabetic Clinic of Ardabil. Iran. Int J Endocrinol Metab, 2006; 4: 8-12.

15. Zenah HA, Moharram M, Imran A, Quazalbash S, Al-Benayan A, Sabry A. Generalized Vascular Damage Including Glomerular Dysfunction in Newly-Detected Type 2 Diabetic Patients . Eur J Gen Med. 2009; 6(1): 28-37.

16. Venugopal S, and lyer UM. Risk Factor Analysis and Prevalence of Microalbuminuria among Type 2 Diabetes Mellitus Subjects: The Need for Screening and Monitoring Microalbumin. Asian J. Exp. Biol. Sci, 2010;1 (3): 652-59.

17. Chiang SC, Lee JK, Chen $\mathrm{CH}$, Chuang LM, Tsan KW, Sheu WHH, et al. Justifying the high prevalence of microalbuminuria for type 2 diabetic patients in Taiwan with conditional probability approach-a DEMAND II Study. Journal of the Chinese Medical Association, 2011; 74(1):3-10.

18. Turaj W, Slowik A, Wyrwicz-Petkow U, Pankiewicz J, Iskra T, Rudziñska M, et al.The prognostic significance of microalbuminuria in non-diabetic acute stroke patients. Med Sci Monit; 2001; 7(5): 989-94.

19. Mykknen L, Zaccaro DJ, O'Leary DH, Howard, G, Robbins DC, Haffner, SM. Microalbuminuria and carotid artery intima-media thickness in nondiabetic and NIDDM subjects. The Insulin Resistance Atherosclerosis Study (IRAS). Stroke. 1997; 28:1710-6.

20. O'Leary DH, Polak JF, Kronmal RA, Manolio TA, Burke GL, Wolfson SK, Jr. Carotid-artery intima and media thickness as a risk factor for myocardial infarction and stroke in older adults. Cardiovascular Health Study Collaborative Research Group. N Engl J Med.1999; 340:14-22.

21. Hillege HL, Fidler V, Diercks GF, van Gilst $\mathrm{WH}$, de Zeeuw D, van Veldhuisen DJ, et al. Urinary albumin excretion predicts 
cardiovascular and noncardiovascular mortality in general population. Circulation, 2002;106(14): 1777-82.

22. Gerstein HC, Mann JF, Yi Q, Zinman B, Dinneen SF, Hoogwerf B et al..Albuminuria and risk of cardiovascular events, death, and heart failure in diabetic and nondiabetic individuals. JAMA. 2001;286 (4): 421-6.

23. Jager A, Kostense PJ, Ruhé HG, Heine RJ, Nijpels G, Dekker JM, et al. Microalbuminuria and peripheral arterial disease are independent predictors of cardiovascular and all-cause mortality, especially among hypertensive subjects: five-year follow-up of the Hoorn Study. Arterioscler Thromb Vasc Biol, 1999;19(3):617-24.

24. Yuyun MF, Khaw KT, Luben R, Welch A, Bingham S, Day N.E, et al. Microalbuminuria and stroke in a British population: the European Prospective Investigation into Cancer in Norfolk (EPIC-Norfolk) population study. J Intern Med. 2004; 255: 247-56.

25. Deckert T, Kofoed-Enevoldsen A, Norgaard $\mathrm{K}$, Borch-Johnsen K, Feldt-Rasmussen B, Jensen T. Microalbuminuria: Implications for micro- and macrovascular disease. Diabetes Care. 1992; 15(9): 1181-91.

26. Winocour PH, Harland JO, Millar J.P, Laker MF, Alberti K.G. Microalbuminuria and associated cardiovascular risk factors in the community. Atherosclerosis, 1992; 93: 71-81.

27. Mattock MB, Barnes DJ, Viberti G, Keen H, Burt D, Hughes JM, et al. Microalbuminuria and coronary heart disease in NIDDM: an incidence study. Diabetes, 1998; 47: 1786-92. 